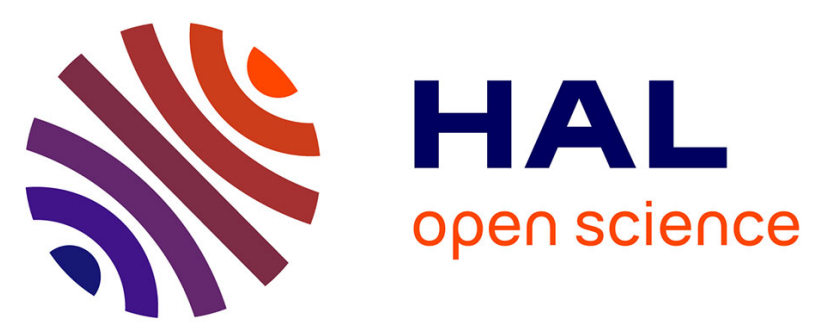

\title{
Controlled atmosphere stunning of broiler chickens: II. Effects on behaviour, physiology and meat quality in a commercial processing plant
}

Dorothy Mckeegan, Siobhan Maya Abeyesinghe, Morven A Mcleman, John C Lowe, Theo G Demmers, Rodger P White, Roland Kranen, Hanneke van Bemmel, Jeannette Ac Lankhaar, Christopher Michael Wathes

\section{To cite this version:}

Dorothy Mckeegan, Siobhan Maya Abeyesinghe, Morven A Mcleman, John C Lowe, Theo G Demmers, et al.. Controlled atmosphere stunning of broiler chickens: II. Effects on behaviour, physiology and meat quality in a commercial processing plant. British Poultry Science, 2007, 48 (04), pp.430-442. 10.1080/00071660701543097 . hal-00545320

\author{
HAL Id: hal-00545320 \\ https://hal.science/hal-00545320
}

Submitted on 10 Dec 2010

HAL is a multi-disciplinary open access archive for the deposit and dissemination of scientific research documents, whether they are published or not. The documents may come from teaching and research institutions in France or abroad, or from public or private research centers.
L'archive ouverte pluridisciplinaire HAL, est destinée au dépôt et à la diffusion de documents scientifiques de niveau recherche, publiés ou non, émanant des établissements d'enseignement et de recherche français ou étrangers, des laboratoires publics ou privés. 


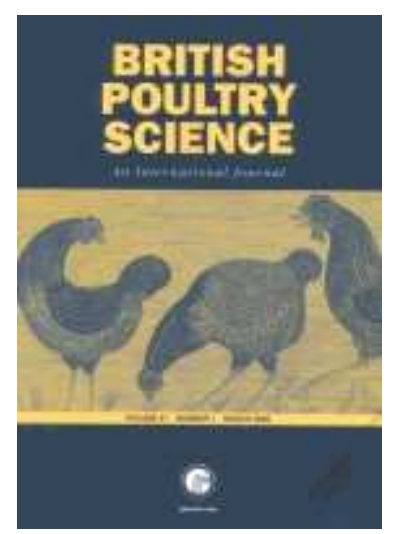

\section{Controlled atmosphere stunning of broiler chickens: II. Effects on behaviour, physiology and meat quality in a commercial processing plant}

\begin{tabular}{|c|c|}
\hline Journal: & British Poultry Science \\
\hline Manuscript ID: & CBPS-2006-152.R1 \\
\hline Manuscript Type: & Original Manuscript \\
\hline $\begin{array}{r}\text { Date Submitted by the } \\
\text { Author: }\end{array}$ & 15-Dec-2006 \\
\hline Complete List of Authors: & $\begin{array}{l}\text { McKeegan, Dorothy; University of Glasgow, Faculty of Veterinary } \\
\text { Medicine } \\
\text { Abeyesinghe, Siobhan; The Royal Veterinary College, Veterinary } \\
\text { Clinical Sciences } \\
\text { McLeman, Morven; The Royal Veterinary College, Veterinary Clinical } \\
\text { Sciences } \\
\text { Lowe, John; The Royal Veterinary College, Veterinary Clinical } \\
\text { Sciences } \\
\text { Demmers, Theo; The Royal Veterinary College, Veterinary Clinical } \\
\text { Sciences } \\
\text { White, Rodger; Rothamsted } \\
\text { Kranen, Roland; Stork PMT } \\
\text { van Bemmel, Hanneke; Stork PMT } \\
\text { Lankhaar, Jeannette; Stork PMT } \\
\text { Wathes, Christopher; The Royal Veterinary College, Veterinary } \\
\text { Clinical Sciences }\end{array}$ \\
\hline Keywords: & Physiology, Broilers, Behaviour, Meat, Welfare, Slaughter \\
\hline
\end{tabular}




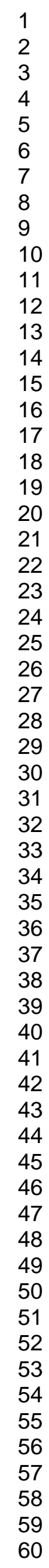

\section{S) ScholarONE}

E-mail: br.poultsci@bbsrc.ac.uk URL: http://mc.manuscriptcentral.com/cbps 

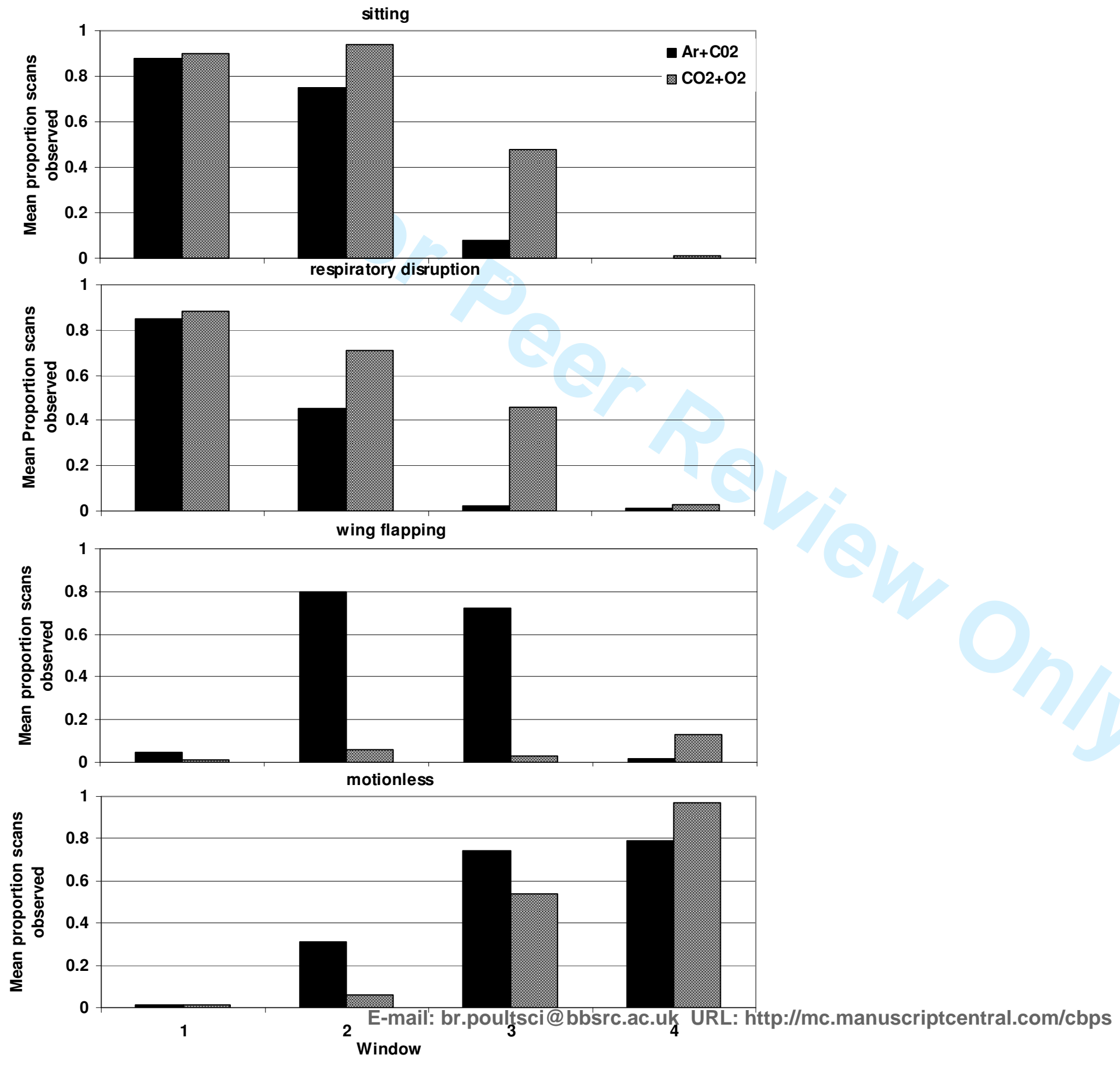
Figure 1. Interactive effects of gas mixture and section of gas chamber (windows 1-4) on mean proportion of scans of posture/behaviour observed and based | on back-transformed means $\left(n=143\right.$ and 118 scans per window for $\mathrm{CO}_{2}+O_{2}$ and $A R+C O_{2}$ respectively). The transformed means on the logit scale, s.e.d.s, Wald statistics and p-values referring to the transformed data are quoted in the text. 


\section{Mean proportion scans behaviour recorded in each gas mixture}

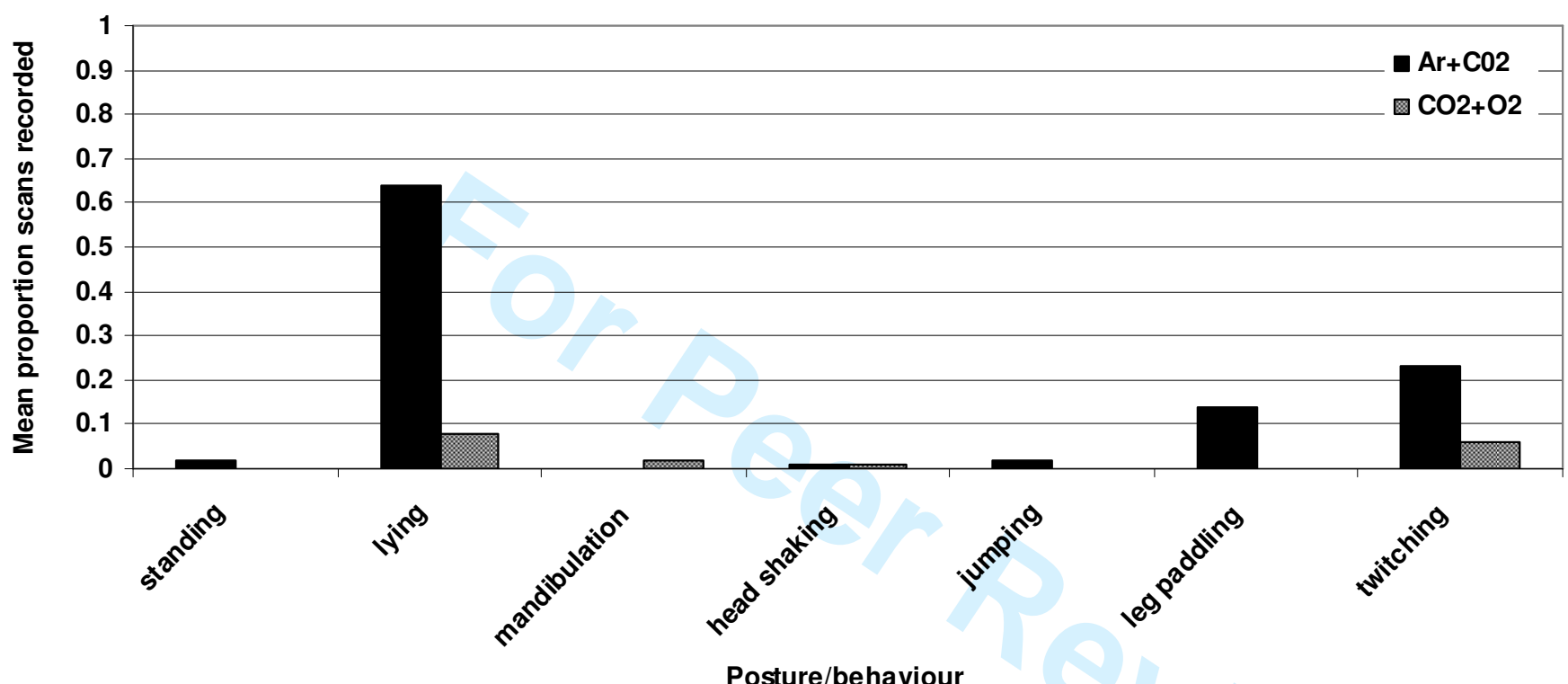

Figure 2. Main effects of gas mixture on mean proportion of scans of posture/behaviour observed based on back-transformed means. Zero scans were recorded for some measurements_ $n=143$ and 118 scans per window for $\mathrm{CO}_{2}+\mathrm{O}_{2}$ and $A R+C O_{2}$, respectively).. The transformed means on the logit scale, s.e.d.s, Wald statistics and p-values referring to the transformed data are quoted in the text. 
Mean proportion scans behaviour recorded at windows

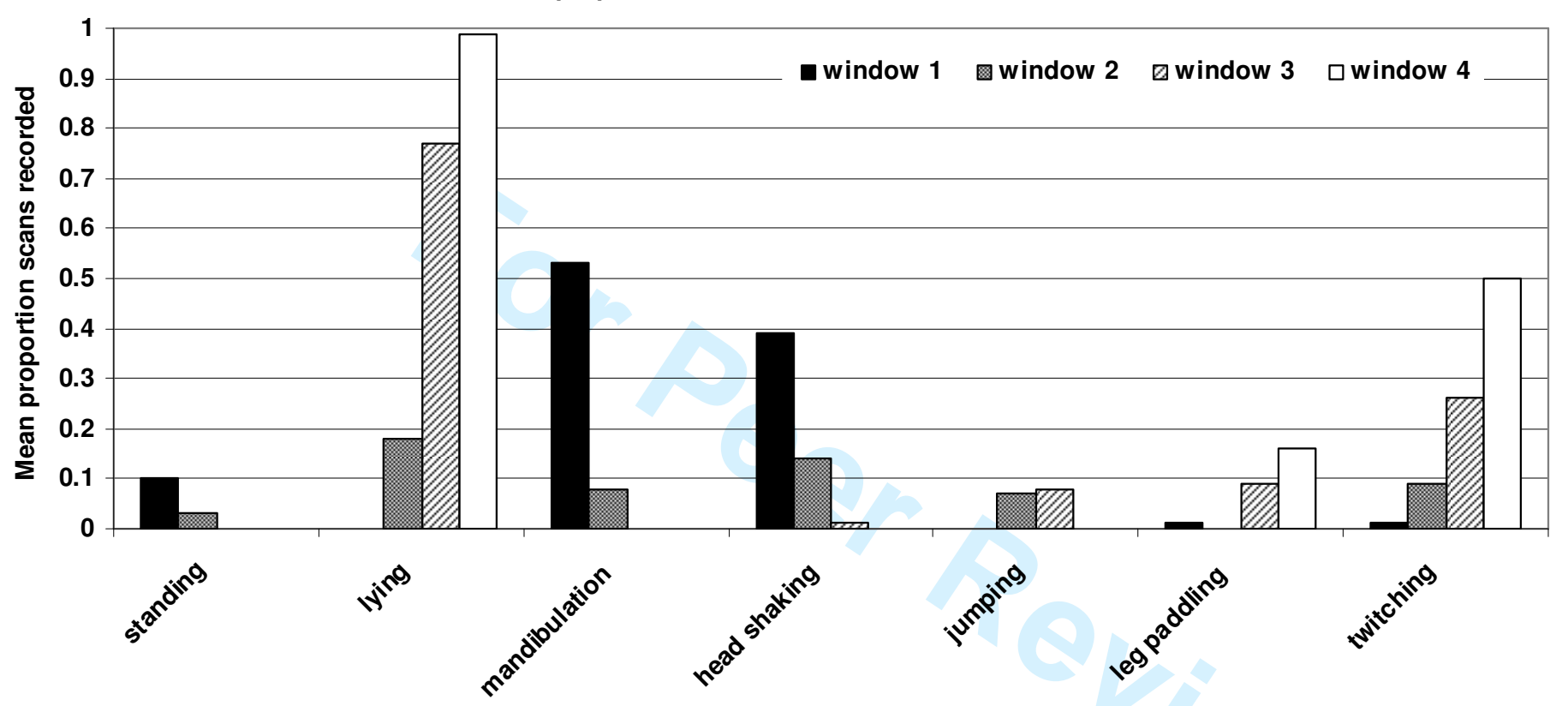

Behaviour

Figure 3. Main effects of window on mean proportion of scans of posture/behaviour observed based on back-transformed means. Zero scans were recorded | for some measurements $\left(n=143\right.$ and 118 scans per window for $\mathrm{CO}_{2}+\mathrm{O}_{2}$ and $\mathrm{AR}+\mathrm{CO}_{2}$ respectively). The transformed means on the logit scale, s.e.d.s, Wald statistics and p-values referring to the transformed data are quoted in the text. 
Proportion lying scans lying positions recorded in different gas mixtures

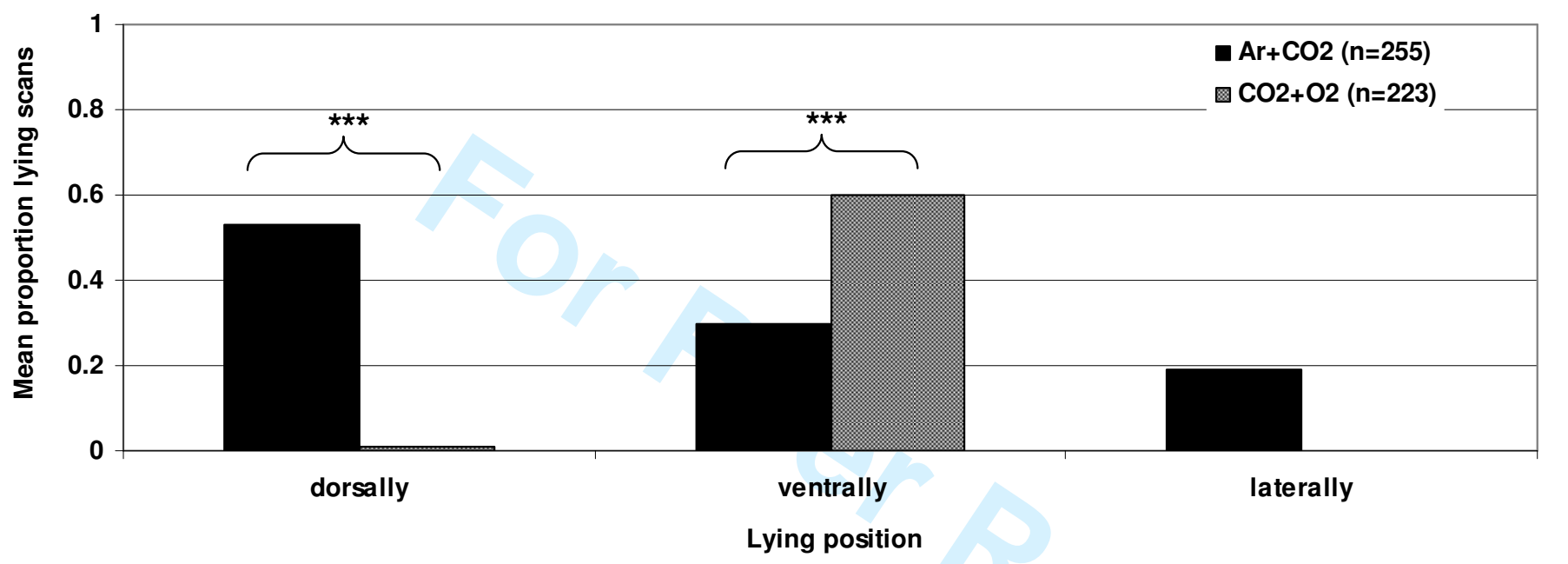

Figure 4. Effects of gas treatment on mean proportion of scans recorded as lying shown as back-transformed means; birds were observed lying dorsally, | ventrally and laterally. Zero scans were recorded for some measurements $\left(n=143\right.$ and 118 scans per window for $\mathrm{CO}_{2}+\mathrm{O}_{2}$ and $\mathrm{AR}+\mathrm{CO}_{2}$, respectively). The transformed means on the logit scale, s.e.d.s, Wald statistics and p-values referring to the transformed data are quoted in the text. 

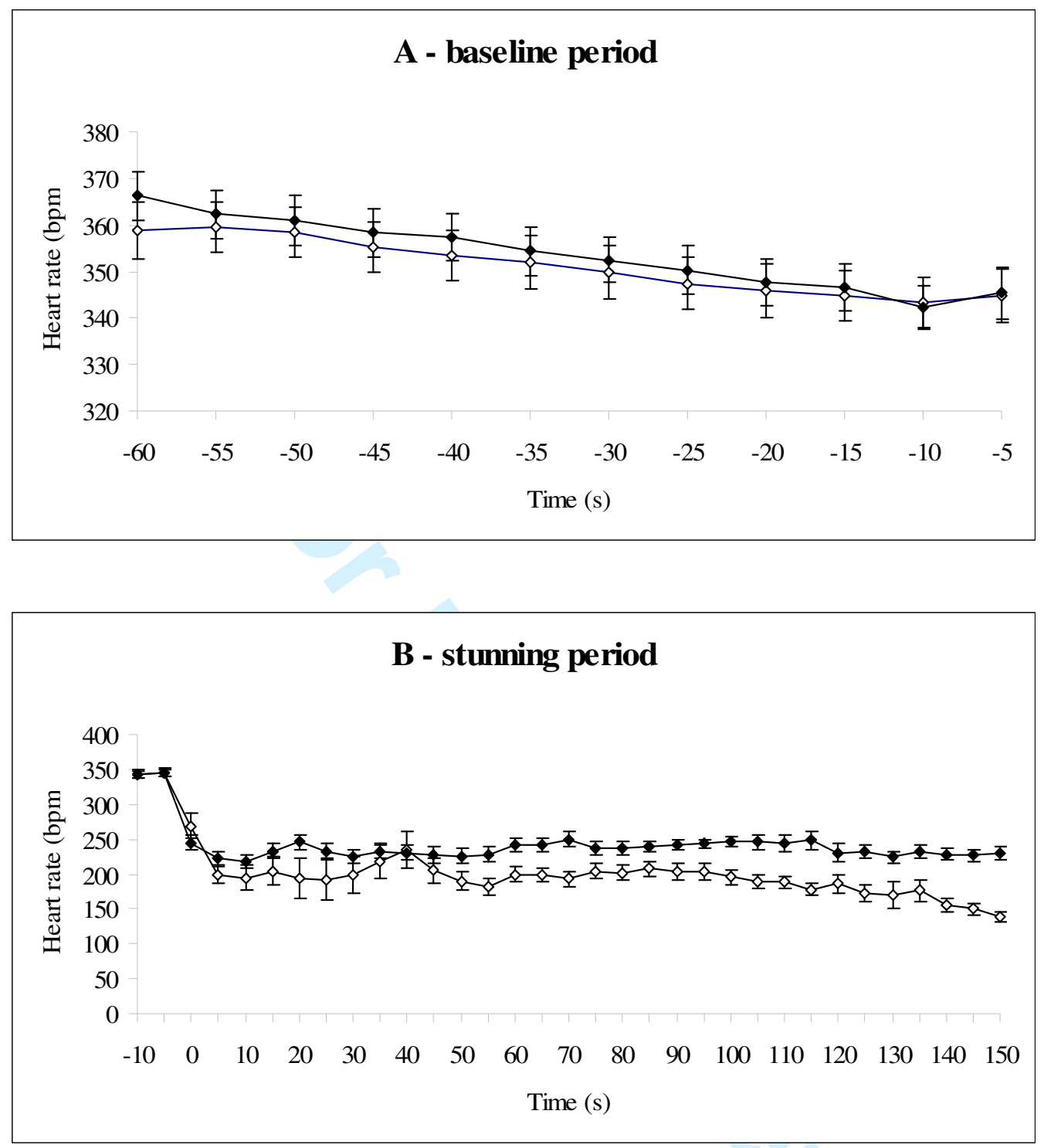

Figure 5. Mean heart rate over time for $A$ ) the baseline period and B) the first 150 s of gas stunning $\left(\mathrm{CO}_{2}+\mathrm{O}_{2}\right.$ : closed circles; $\mathrm{Ar}+\mathrm{CO}_{2}$ : open circles). Error bars represent standard | errors. $n=45$ birds for each gas treatment. 


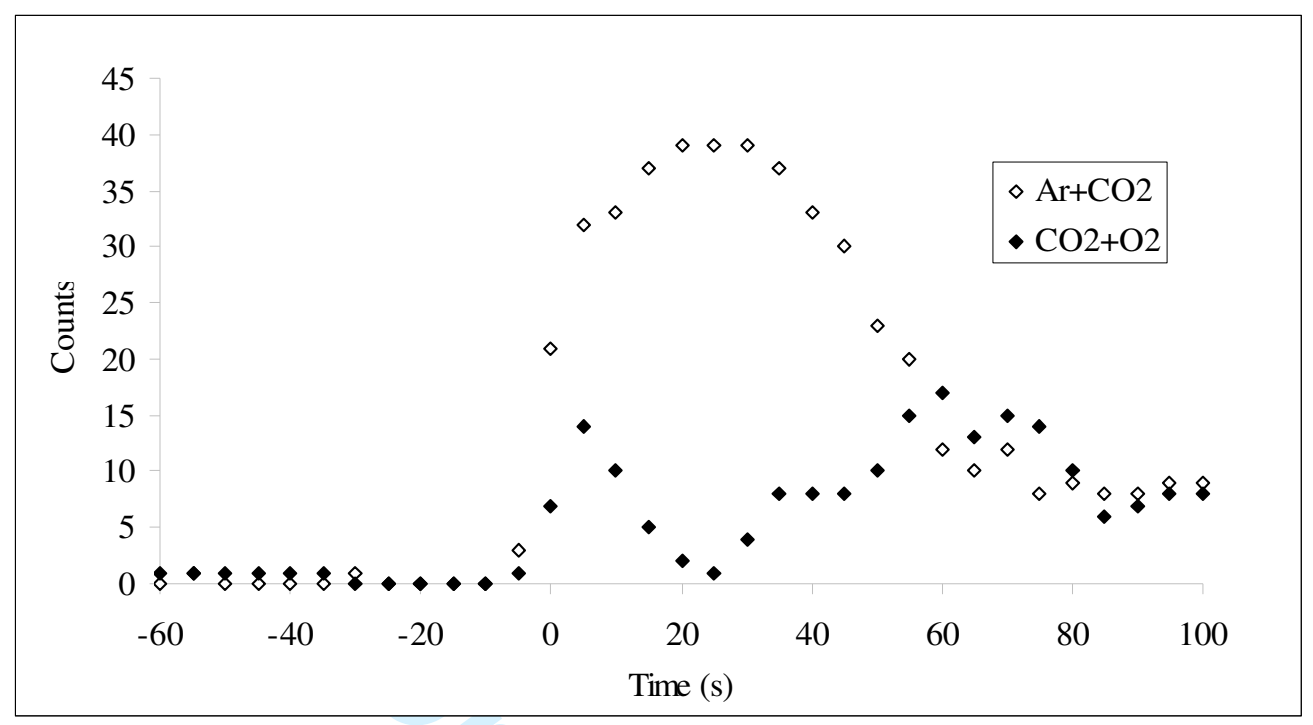

Figure 6. Number of segments of obscured ECG traces for broiler chickens ( $n=45$ birds per treatment) stunned by gas for each 5 s time period. 
Controlled atmosphere stunning of broiler chickens: II. Effects on behaviour, physiology and meat quality in a commercial processing plant

D.E.F. MCKEEGAN, S.M. ABEYESINGHE ${ }^{1}$, M.A. MCLEMAN ${ }^{1}$, J.C. LOWE ${ }^{1}$, T.G.M. DEMMERS ${ }^{1}$, R.P. WHITE ${ }^{2}$, R.W. KRANEN ${ }^{3}$, H. VAN BEMMEL ${ }^{3}$, J.A.C. LANKHAAR $^{3}$ AND C.M. WATHES ${ }^{1}$

Division of Animal Production and Public Health, Faculty of Veterinary Medicine, University of Glasgow, Glasgow, Scotland, ${ }^{1}$ The Royal Veterinary College, University of London, Hatfield, Hertfordshire, England, ${ }^{2}$ Rothamsted Research, Harpenden, Hertfordshire, England and ${ }^{3}$ Stork Food Systems, , 5830 AC Boxmeer, The Netherlands

Short title: Controlled atmosphere stunning of broilers. II

Correspondence to Prof. C. M. Wathes, The Royal Veterinary College, University of London, Hawkshead Lane, North Mymms, Hatfield, Hertfordshire, AL9 7TA, UK

Tel: 01707666 361; Fax: 01707666298 cmwathes@rvc.ac.uk; 


\begin{abstract}
The effects of controlled atmosphere stunning on behavioural and physiological responses, and carcase and meat quality of broiler chickens were studied experimentally in a full-scale processing plant.

2. The gas mixtures tested were a single phase hypercapnic anoxic mixture of $60 \% \mathrm{Ar}$ and $30 \% \mathrm{CO}_{2}$ in air with $<2 \% \quad \mathrm{O}_{2}$, and a biphasic hypercapnic hyperoxygenation mixture, comprising an anaesthetic phase, $40 \% \mathrm{CO}_{2}, 30 \% \mathrm{O}_{2}, 30 \% \mathrm{~N}_{2}$, followed by an euthanasia phase: $80 \% \mathrm{CO}_{2}, 5 \% \mathrm{O}_{2}, 15 \% \mathrm{~N}_{2}$.

3. Birds stunned with $\mathrm{Ar}+\mathrm{CO}_{2}$ were more often observed to flap their wings earlier, jump, paddle their legs, twitch, and lie dorsally (rather than ventrally) than those stunned with $\mathrm{CO}_{2}+\mathrm{O}_{2}$. These behaviours indicate a more agitated response with more severe convulsions during hypercapnic anoxia, thereby introducing greater potential for injury.

4. Heart rate during the first $100 \mathrm{~s}$ of gas stunning was similar for both gases, after which it remained constant at $\approx 230$ beats $/ \mathrm{min}$ for $\mathrm{CO}_{2}+\mathrm{O}_{2}$ birds whereas it declined gently for $\mathrm{Ar}+\mathrm{CO}_{2}$ birds.

5. In terms of carcase and meat quality, there appeared to be clear advantages to the processor in using $\mathrm{CO}_{2}+\mathrm{O}_{2}$ rather than $\mathrm{Ar}+\mathrm{CO}_{2}$ to stun broiler chickens, for example, a much smaller number of fractured wings (1.6 vs. $6.8 \%$ ) with fewer haemorrhages of the fillet.

6. This study supports the conclusions of both laboratory and pilot scale experiments that controlled atmosphere stunning of broiler chickens based upon a biphasic hypercapnic hyperoxygenation approach has advantages, in terms of welfare and carcase and meat quality, over a single phase hypercapnic anoxic approach employing $60 \% \mathrm{Ar}$ and $30 \% \mathrm{CO}_{2}$ in air with $<2 \% \mathrm{O}_{2}$.
\end{abstract}




\section{INTRODUCTION}

Within Europe and North America, electrical stunning using a constant voltage is the most common technique by which poultry are stunned prior to slaughter. However, despite the advantages of low cost and proven reliability, there are concerns (Raj and Tserveni-Gousi, 2000) about the humaneness of electrical stunning that can be overcome by the alternative technique of controlled atmosphere stunning (CAS). The major disadvantages of electrical stunning include manual handling, inversion, shackling and the variable current experienced, all of which adversely affect animal welfare.

There are many laboratory studies of the behavioural and physiological responses of the fowl during CAS (Woolley and Gentle, 1988; Raj and Gregory, 1990; Raj et al., 1998; Lambooij et al., 1999; Coenen et al., 2000; Gerritzen et al., 2000; Webster and Fletcher, 2001; and McKeegan et al., 2006). In general, these support the contention that in terms of the overall system from arrival at the abattoir to death, CAS is more humane than electrical stunning but there are still doubts over the choice of gases to be used. Furthermore, the experimental conditions of laboratory studies differ in some key respects from those in processing plants, which may call into question the interpretation of laboratory findings, due to the presence of other birds or the atmosphere experienced.

In a comprehensive, coordinated project, we have examined the humaneness of CAS at various scales and degrees of refinement in the laboratory, a pilot scale CAS system and a full scale processing plant. This paper is the last in a series (Abeyesinghe et al., 2007; Lowe et al. 2007; McKeegan, 2004; McKeegan et al., 2006; 2007) reporting the results of this project. Here, we describe the behavioural and physiological reactions of broiler chickens to CAS under commercial conditions in a full-scale processing plant. An assessment was also made of carcase and meat quality. Broiler chickens were stunned by one of two gas mixtures that tested alternative approaches to stunning; i) a single phase hypercapnic anoxic mixture consisting of $60 \%$ Ar and $30 \% \mathrm{CO}_{2}$ in air with $<2 \% \mathrm{O}_{2}$ (' $\left.\mathrm{Ar}+\mathrm{CO}_{2}{ }^{\prime}\right)$; and ii) a biphasic hypercapnic hyperoxygenation mixture, comprising an anaesthetic phase with a gas mixture of $40 \% \mathrm{CO}_{2}, 30 \% \mathrm{O}_{2}, 30 \% \mathrm{~N}_{2}$, followed by an euthanasia phase with $80 \% \mathrm{CO}_{2}, 5 \% \mathrm{O}_{2}, 15 \%$ $\mathrm{N}_{2}\left({ }^{\prime} \mathrm{CO}_{2}+\mathrm{O}_{2}\right.$ '). Both approaches are used commercially in continental Europe, though only $\mathrm{Ar}+\mathrm{CO}_{2}$ is permitted in the United Kingdom.

\section{MATERIALS AND METHODS}

Many of the materials and methods used in this experiment were similar to those reported in the accompanying paper (Abeyesinghe et al., 2007). Groups of mature broiler chickens were stunned by gas in a commercial processing plant using one of two gas mixtures. Detailed observations of the behaviour, and measurements of heart and respiration rates were made 
prior to and during stunning. Carcase and meat quality were assessed after stunning. The experiment lasted $5 \mathrm{~d}$; both treatments were applied on each day.

\section{Full-scale processing plant}

The commercial processing plant was located in Belgium and ran at an average throughput of 9000 birds/h during the experiment, which took place between August 30 and September 3 2004. The CAS plant was manufactured by Stork Food Systems. Birds were loaded automatically from a transport crate on to a conveyor. They were then passed sequentially through a tunnel of two chambers in which the atmosphere could be controlled. The first chamber measured $9400 \times 759 \times 350 \mathrm{~mm}(1 \times \mathrm{w} \times \mathrm{h})$; the second chamber was divided into two parts, measuring $11250 \times 750 \times 430$ and $11800 \times 500 \times 375 \mathrm{~mm}$, respectively. The normal period of exposure was 64 and $118 \mathrm{~s}$ in the first and second chambers respectively, but this was affected by the bird's movement on the conveyor. Gas concentration was controlled and monitored continuously by a Hydro $\mathrm{MACS}^{\mathrm{TM}}$ stunning control system (Yara International ASA, Oslo, Norway), measuring independently the concentration of $\mathrm{CO}_{2}$ and $\mathrm{O}_{2}$ within the flow in phase 1 , and $\mathrm{CO}_{2}$ in phase 2; the Ar concentration was inferred from the oxygen concentration. Additional measurement of the gas concentration was performed at a single location at the bird's head height within the chamber using a gas analyser (PBI Dansensor Checkpoint, Model 200548/210661). The mean ( \pm s.d.) concentrations of $\mathrm{CO}_{2}$ and $\mathrm{O}_{2}$ in the first and second chambers were: (i) $\mathrm{CO}_{2}+\mathrm{O}_{2}$ mixture, chamber $1-\mathrm{CO}_{2} 40.0 \pm 0.6 \%, \mathrm{O}_{2} 30.0$ $\pm 0.4 \%$; chamber $2-\mathrm{CO}_{2} 80.0 \pm 0.7 \%$; and (ii) $\mathrm{Ar}+\mathrm{CO}_{2}$ mixture, chamber $1 \mathrm{CO}_{2} 30.1 \pm$ $1.7 \%, \mathrm{O}_{2} 1.3 \pm 0.6 \%$, Ar $58.6 \%$. The atmosphere within the first chamber was humidified to $60-80 \pm 10 \%$ relative humidity, following commercial practice.

After stunning, the birds were shackled by their legs and killed automatically by a unilateral cut to one carotid artery and one jugular vein in the neck, the whole process taking approximately $25 \mathrm{~s}$. The carcases were then bled for $3 \mathrm{~min}$, scalded at $53.5^{\circ} \mathrm{C}$ for $3 \mathrm{~min}$, and plucked. After evisceration, the carcases were chilled by air for $30 \mathrm{~min}$ at $-0.5^{\circ} \mathrm{C}$ and then for a further $1.75 \mathrm{~h}$ at 0.5 to $1^{\circ} \mathrm{C}$. Carcases, which were to be analysed for meat quality, were collected after leaving the chiller and stored at $0.5^{\circ} \mathrm{C}$ until manual de-boning, except for those which were examined at $1.5 \mathrm{~h}$ post mortem.

\section{Behavioural and physiological observations}

The methods used to observe the behavioural and physiological reactions of the birds to CAS are described by Abeyesinghe et al. (2007) and measurements were made daily for three days with each gas treatment applied on each day. The gas treatments were applied sequentially while the processing line was running at 9000 birds/h. A short break was needed between batches to allow the tunnel to be purged before a new gas mixture was introduced to the stunning chambers. All birds used in paired batches originated from the same flock. 
Physiological measurements of heart and respiration rate were made on a total of 90 individuals (15 per treatment per day), each of which was fitted with a telemetric/logging system mounted on a body harness (Lowe et al., 2007; method described in Abeyesinghe et al. (2007)). Measurements were made for $60 \mathrm{~s}$ to establish a baseline while the bird was sitting on a table adjacent to the loading conveyor. The bird was then placed on the conveyor at the entrance to the tunnel, thereby rejoining a continuous stream of broiler chickens that were to be processed. Respiration rate was determined every $5 \mathrm{~s}$ from an average over the preceding $5 \mathrm{~s}$. Heart rate was calculated from the ECG trace at $5 \mathrm{~s}$ intervals for the baseline and stunning periods. During the recordings, the ECG waveform was occasionally obscured (sometimes for long periods) by electromyogram activity from the pectoral muscles and movement artefacts arising from a combination of either wing flapping and/or prolonged muscle contractions.

For the behavioural measurements, cameras were placed at 4 (out of 6) viewing windows along the length of the first chamber, which was lit artificially. This allowed an estimate to be made of the approximate time since entry to the tunnel. The positions and timings were: window 1, 0-8 s; window 2, 9-16 s; window 3, 17-24 s; and window 4, 33-40 s. It was not possible to view the birds in the second chamber because of the low light intensity. The number of birds being processed rendered it impossible to visually track harnessed individuals via these viewing stations so instead recordings were made continuously for the duration of all trials with each gas treatment.

Scan sampling at $3 \mathrm{~min}$ intervals was conducted on these continuously-recorded data. For each scan, the observer selected the first observable bird passing nearest the window camera from which to record its behaviour, with the provisos that the chamber was full of birds and the conveyor was moving to maintain condition consistency. These provisos occasionally meant the scan was delayed by up to a maximum of $2 \mathrm{~min}$, but on average only $5 \mathrm{~s}$. The behaviour categories recorded were similar to those used by Abeyesinghe et al. (2007) in the pilot scale system with the addition of some new postural categories. The bird's posture was described as: i) lie bird lying (ventrally, dorsally or laterally) with body in contact with the conveyor and supine head; ii) sit - bird sitting with sternum in contact with the conveyor with an erect head; and iii) stand - bird standing upright on two legs. Several behaviours and the bird's posture could be recorded from each scan. In total, scans of 472 and 572 individual birds from the $\mathrm{Ar}+\mathrm{CO}_{2}$ and $\mathrm{CO}_{2}+\mathrm{O}_{2}$ treatments, respectively were observed.

\section{Measurement of carcase and meat quality}

A comprehensive set of measurements were made to determine the effects of stunning gas on carcass and meat quality; the methods are described in detail by Abeyesinghe et al. (2007). Table 1 shows the measurements that were made for each gas treatment on 6 flocks over 5 
successive days, two days longer than the period over which behavioural and physiological measurements were made.

Table 1 here

\section{Statistical analysis}

Genstat, release 6.2 (6 $6^{\text {th }}$ edition) for Windows@ (1998 Lawes Agricultural Trust IACR), was used to perform the statistical analyses. For the behavioural data, Generalised Linear Mixed Model (GLMM: Marginal Model; Binomial distribution with logit link function) analyses were conducted on the proportion of total scans of each behaviour observed. All behavioural analyses used the treatment structure (in Genstat notation) of gas*window and a blocking structure of 'day' where gas described the two different gas mixtures $\left(\mathrm{Ar}+\mathrm{CO}_{2}\right.$ and $\left.\mathrm{CO}_{2}+\mathrm{O}_{2}\right)$, 'window' indicated which the viewing window at which behaviour was observed and 'day' represented days 1-3 of the experiment. All behavioural data were transformed using the logit. For the physiological data, arithmetic means and s.e.'s were calculated and visual comparisons made.

The carcase and meat quality data were analysed using ANOVA or regression analysis. For measurements made at a single time, the treatment structure was 'gas' with a blocking structure of flock/bird, where 'flock' indicates the source of the birds and bird indicates the individual. Where measurements were taken at various de-boning times, the treatment structure was gas*time; 'time' was log-transformed and linear and quadratic trends were determined using low order (up to second) polynomial contrasts. Transforming de-boning time made the steps between de-boning times more linear. Shear force data were transformed using logarithms. The blocking structure was flock/gas/time/bird. Analysis of deviance with a logit link was also used for variates with a binomial distribution, such as liver colour and wing fractures.

\section{RESULTS}

\section{Behaviour}

In total 1044 scans of behaviour were recorded; 143 scans per window on the $\mathrm{CO}_{2}+\mathrm{O}_{2}$ treatment and 118 scans per window on the $\mathrm{Ar}+\mathrm{CO}_{2}$ treatment. The posture and behaviour categories are discussed individually. The transformed means, s.e.d.'s, Wald statistic and $P$ value for relevant treatment comparisons are given in parentheses for each behaviour; Figures 1 to 4 inclusive show the back-transformed means for each behaviour (either for the two gas mixtures or for the four windows, in order). The birds remained in the first chamber for approximately $75 \mathrm{~s}$, which was defined as the first phase of exposure, while the second phase lasted from about 75 to $185 \mathrm{~s}$. 


\section{Standing}

Standing was recorded on only $3 \%$ of scans in total. There was no difference in occurrence between the gas mixtures (Figure 2: mean $\mathrm{Ar}+\mathrm{CO}_{2}$ and $\mathrm{CO}_{2}+\mathrm{O}_{2}=-3.86$ and -7.03 , s.e.d. $=$ 4.97, $W_{1}=0.83, P=0.362$ ) and, as expected it sharply declined after the first window (Figure 3: mean $=-2.25,-3.60,-7.97$ and -7.97 , s.e.d. $\left.=0.46, W_{3}=16.82, P<0.001\right)$.

Sitting

Sitting was the most frequently recorded posture, occurring on $51 \%$ of scans. There was an interactive effect of gas type and duration in the chamber (Figure 1: mean $\mathrm{Ar}+\mathrm{CO}_{2}=2.01$, 1.08, -2.50 and -10.98 and mean $\mathrm{CO}_{2}+\mathrm{O}_{2}=2.22,2.83,-0.07$ and -4.26 , s.e.d. $=4.84 \mathrm{~W}_{3}=$ 10.0, $P=0.018$ ) with a decline in sitting across windows (as birds progressed) in both gas mixtures but this occurred more steeply in $\mathrm{Ar}+\mathrm{CO}_{2}$ than $\mathrm{CO}_{2}+\mathrm{O}_{2}$.

Lying

Overall, lying was recorded on $46 \%$ of scans. There was no difference in occurrence between the gas mixtures (Figure 2: mean $\mathrm{Ar}+\mathrm{CO}_{2}$ and $\mathrm{CO}_{2}+\mathrm{O}_{2}=0.58$ and -2.44, s.e.d. $=3.95, W_{1}=$ $0.03, P=0.858$ ), however further analysis indicated lying posture was affected by the gas treatment; more birds were recorded lying dorsally in $\mathrm{Ar}+\mathrm{CO}_{2}$ (Figure 4: mean $\mathrm{Ar}+\mathrm{CO}_{2}$ and $\mathrm{CO}_{2}+\mathrm{O}_{2}=0.11$ and -4.6 , s.e.d. $=0.75, W_{1}=39.34, P<0.001$ ), and more lying ventrally in $\mathrm{CO}_{2}+\mathrm{O}_{2}$ (Figure 4: mean $\mathrm{Ar}+\mathrm{CO}_{2}$ and $\mathrm{CO}_{2}+\mathrm{O}_{2}=-0.83$ and 0.42, s.e.d. $=0.25, W_{1}=25.58, P<$ 0.001). Observations of birds lying laterally did not differ between gases (Figure 4: mean $\mathrm{Ar}+\mathrm{CO}_{2}$ and $\mathrm{CO}_{2}+\mathrm{O}_{2}=-1.48$ and -7.13 , s.e.d. $\left.=11.54, W_{1}=0.24, P=0.627\right)$. As expected, $\mathrm{a}$ sharp increase in lying occurred across windows, particularly at window 3 (Figure 3: mean = 7.43, $-2.02,1.23$ and 4.51 , s.e.d. $\left.=0.32 W_{3}=178.50, P<0.001\right)$.

\section{Respiratory disruption}

Respiratory disruption was recorded on $43 \%$ of scans overall. It occurred progressively less as birds moved along the chamber (from windows 1 to 4 ) in both gas mixtures, with little difference between treatments at window 1, but continued at a high occurrence for longer in $\mathrm{CO}_{2}+\mathrm{O}_{2}$ than $\mathrm{Ar}+\mathrm{CO}_{2}$ and (Figure 1: mean $\mathrm{Ar}+\mathrm{CO}_{2}=1.71,-0.21,-4.06$ and -4.76 and mean $\mathrm{CO}_{2}+\mathrm{O}_{2}=2.01,0.92,-0.14$ and -3.54 , s.e.d. $\left.=0.86, W_{3}=10.7, P=0.014\right)$.

\section{Mandibulation}

Mandibulation occurred on only $16 \%$ of scans overall and was equally apparent in both mixtures (Figure 2: mean $\mathrm{Ar}+\mathrm{CO}_{2}$ and $\mathrm{CO}_{2}+\mathrm{O}_{2}=-6.28$ and -3.98, s.e.d. $=6.60, W_{1}=0.23, P$ $=0.630$ ), declining in occurrence sharply after the first window (Figure 3 : mean $=0.12,-2.43$, -7.14 and -11.06 , s.e.d. $\left.=0.31, W_{3}=108.07, P<0.001\right)$.

\section{Head shaking}

Head shaking, occurring on only $13 \%$ of scans in total and followed a similar pattern to mandibulation, with no difference between gas mixtures (Figure 2: mean $\mathrm{Ar}+\mathrm{CO}_{2}$ and 
$\mathrm{CO}_{2}+\mathrm{O}_{2}=-4.59$ and -4.33 , s.e.d. $\left.=6.73, W_{1}=0.30, P=0.585\right)$ and a decline across the first two windows, with few birds observed head shaking after window 2 (Figure 3: mean $=-0.44$, $-1.82,-4.51$ and -11.08 , s.e.d. $\left.=0.31, W_{3}=38.40, P<0.001\right)$.

Wing flapping

Wing flapping occurred on $21 \%$ of all scans. Significantly more wing flapping was recorded in $\mathrm{Ar}+\mathrm{CO}_{2}$ than $\mathrm{CO}_{2}+\mathrm{O}_{2}$ and this mostly occurred in the second and third windows, tailing off sharply at the final viewing point (Figure 1: mean $\mathrm{Ar}+\mathrm{CO}_{2}=-2.93,1.37,0.95$ and -4.06 and mean $\mathrm{CO}_{2}+\mathrm{O}_{2}=-4.96,-2.83,-3.55$ and -1.88 , s.e.d. $\left.=0.89, W_{3}=38.3, P<0.001\right)$.

\section{Jumping}

Jumping was recorded on approximately $10 \%$ of all scans, almost exclusively in $\mathrm{Ar}+\mathrm{CO}_{2}$ (Figure 2: mean $\mathrm{Ar}+\mathrm{CO}_{2}$ and $\mathrm{CO}_{2}+\mathrm{O}_{2}=-3.78$ and -5.88, s.e.d. $=0.37, W_{1}=32.71, P<0.001$ ). It was generally associated with wing flapping, occurring largely in the two mid-windows (Figure 3: mean $=-7.26,-2.58,-2.46$ and -7.03 , s.e.d. $=0.916, W_{3}=17.97, P<0.001$ ) and indicates a greater severity of convulsion.

Leg paddling

Leg paddling was recorded on $11 \%$ of all scans, again almost exclusively in $\mathrm{Ar}+\mathrm{CO}_{2}$ (Figure 2: mean $\mathrm{Ar}+\mathrm{CO}_{2}$ and $\mathrm{CO}_{2}+\mathrm{O}_{2}=-1.82$ and -5.80, s.e.d. $=0.85, W_{1}=21.68, P<0.001$ ) and increasing in occurrence across windows (Figure 3: mean $=-4.50,-6.76,-2.29$ and -1.68 , s.e.d. $\left.=0.68, W_{3}=20.14, P<0.001\right)$.

\section{Twitching}

Twitching occurred on $23 \%$ of all scans and was observed significantly more in $\mathrm{Ar}+\mathrm{CO}_{2}$ than $\mathrm{CO}_{2}+\mathrm{O}_{2}$ (Figure 2: mean $\mathrm{Ar}+\mathrm{CO}_{2}$ and $\mathrm{CO}_{2}+\mathrm{O}_{2}=-1.24$ and -2.69, s.e.d. $=0.53, W_{1}=7.64, P=$ 0.006). Its occurrence also increased across windows (Figure 3: mean $=-4.50,-2.33,-1.03$ and 0.01, s.e.d. $\left.=0.29, W_{3}=43.88, P<0.001\right)$.

\section{Motionless}

Motionless increased later in $\mathrm{CO}_{2}+\mathrm{O}_{2}$ than $\mathrm{Ar}+\mathrm{CO}_{2}$, but a significantly greater proportion of scans recorded motionless in the final window for $\mathrm{CO}_{2}+\mathrm{O}_{2}$ compared with $\mathrm{Ar}+\mathrm{CO}_{2}$ (Figure 1: mean $\mathrm{Ar}+\mathrm{CO}_{2}=-4.75,-0.81,1.05$ and 1.33 and mean $\mathrm{CO}_{2}+\mathrm{O}_{2}=-4.96,-2.83,0.15$ and 3.54, s.e.d. $=1.38, \mathrm{~W}_{3}=10.5, P=0.15$ ). This may have been due to the more frequent occurrence of other behaviours seen in $\mathrm{Ar}+\mathrm{CO}_{2}$.

Figs 1-4 here

\section{Heart rate and respiration rate}

Figure 5 shows the mean heart rate of the birds during the baseline period and the first $150 \mathrm{~s}$ of stunning. Heart rate fell slightly from about 360 beats/min when the birds were caught and fitted with a harness to about 350 beats/min when they were placed on the conveyor to enter 
Figs 5 and 6 here

\section{Carcase and meat quality}

Table 2 shows the results of the measurements of carcase and meat quality. Some, but not all, of the measures were affected significantly by the gas used to stun the birds. Blood loss (approximately $3 \%$ by weight), skin damage and liver colour were similar in both treatments. Overall, the number of carcases with fractured wings $(P<0.001)$ and the mean score for fillet haemorrhages $(P=0.05)$ was significantly higher for $\mathrm{Ar}+\mathrm{CO}_{2}$ than $\mathrm{CO}_{2}+\mathrm{O}_{2}$. The number of wings examined was 9110 and 9930 for the $\mathrm{Ar}+\mathrm{CO}_{2}$ and $\mathrm{CO}_{2}+\mathrm{O}_{2}$ treatments, respectively. By far the most common fractures were of the wrist and elbow joint $\left(\mathrm{Ar}+\mathrm{CO}_{2} 3.9\right.$ and 2.4\%; $\mathrm{CO}_{2}+\mathrm{O}_{2} 0.8$ and $0.8 \%$ ); there were few fractures of the humerus and radius/ulna and none of the wing tips. In terms of fractured wings, the prevalence of breakages with or without perforation of the skin was between 5 and 6 times higher for $\mathrm{Ar}+\mathrm{CO}_{2}$ than $\mathrm{CO}_{2}+\mathrm{O}_{2}$; overall, the prevalence of fractured wings of both types was 6.8 and $1.6 \%$, respectively.

Table 2 here

Various measures of meat quality over time are shown in Table 3. There was a significant interaction between time and gas for fillet $\mathrm{pH}$ but it could not be explained by a simple linear or quadratic trend $(P<0.001)$. Fillet pH rose initially for $\mathrm{CO}_{2}+\mathrm{O}_{2}$, but not $\mathrm{Ar}+\mathrm{CO}_{2}$, carcases and final $\mathrm{pH}$ was reached $15 \mathrm{~min}$ after post mortem for $\mathrm{Ar}+\mathrm{CO}_{2}$ but not until $5 \mathrm{~h}$ for $\mathrm{CO}_{2}+\mathrm{O}_{2}$. There were main effects of gas and time on shear force, measured immediately after deboning $\left(\mathrm{t}_{0}\right)$ and after $24 \mathrm{~h}$ storage $\left(\mathrm{t}_{24}\right)$; shear force fell non-linearly with time, was highest in $\mathrm{CO}_{2}+\mathrm{O}_{2}$ and did not stabilise until about $7 \mathrm{~h}$ post mortem. Neither storage nor cooking losses 
were affected by the gas treatment nor did they change with time; they were about $0.5 \%$ and $25 \%$ respectively.

Table 3 here

The results of the measurements of the colour of the fillets are given in Table 4 using the CIELab convention. There were no interactions between gas and time. The distal surface of the fillets was darkest for $\mathrm{Ar}+\mathrm{CO}_{2}(P=0.003)$ and there was a similar trend for the proximal surface (ns). Some changes were also observed over time; the distal surface of the fillets became paler and less red, while the proximal surface became less yellow.

Table 4 here

\section{DISCUSSION}

In general, these experimental findings supports those of the accompanying paper (Abeyesinghe et al.; 2007) on the reactions and responses of broiler chickens to CAS. This study employed the same techniques as the latter but extended the scope from a pilot scale system to the full scale conditions of the commercial processing plant, while still employing a common scientific approach. To the best of our knowledge this is the first report of the effects of CAS on broiler chickens in the processing plant on such a large scale.

The behavioural responses of the birds followed a logical sequence in terms of their physiological and behavioural reactions to CAS, though it should be noted that our observations were restricted to the first $40 \mathrm{~s}$ of stunning. Most birds were sitting on entry to the gas tunnel and their initial reaction to the stunning gas was mandibulation and head shaking, showing that they had detected the gas either directly via chemo-receptors or indirectly via consequential physiological effects. Subsequently - and in an approximate order of occurrence - they sat down, showed signs of respiratory disruption, flapped their wings, lay down, paddled their legs, jumped, and twitched before becoming motionless. However, this sequence differed in some aspects for the two gases. Birds stunned with $\mathrm{Ar}+\mathrm{CO}_{2}$ were more often observed to flap their wings earlier, jump, paddle their legs, twitch, and lie dorsally (rather than ventrally) than those stunned with $\mathrm{CO}_{2}+\mathrm{O}_{2}$. These behaviours have the potential to cause distress if the birds are conscious; similar observations were made by Lambooij et al. (1999) and Abeyesinghe et al. (2007). In particular, our findings for lying position, wing flapping and jumping indicate more severe convulsions during hypercapnic anoxia, thereby introducing greater potential for injury for both the bird itself and its companions. Indeed, the high prevalence of wing fractures in $\mathrm{Ar}+\mathrm{CO}_{2}$ demonstrates the force of the bird's movements and convulsions in this gas mixture. This is a welfare issue only if birds were sensible at any 
time during these convulsions; our laboratory findings McKeegan et al. (2006b) describing EEG signals during this period suggest that this is a possibility.

It would have been advantageous to have recorded the vocalisations made by the birds because these would have been indicative of their state of anxiety, fear or distress, but to the best of our knowledge there are no published measurements of vocalisations during CAS. It is not known whether the sight, sound and smell of one bird dying are distressing to another (conscious) bird although the physical proximity of others may result in disturbance or even injury; sheep are apparently unaffected when a conspecific is killed in their presence (Anil et al. 1996). Respiratory disruption was more common and continued for longer in $\mathrm{CO}_{2}+\mathrm{O}_{2}$ than $\mathrm{Ar}+\mathrm{CO}_{2}$, but the interpretation of this finding is complicated by the fact that one of the mixtures $\left(\mathrm{Ar}+\mathrm{CO}_{2}\right)$ was both hypercapnic and anoxic and thus may have induced both types of disruption that were included in this behavioural category. However, McKeegan et al. (2006; 2007) reported increased respiratory disruption in response to hypercapnic hyperoxygenation, an observation supported by the current findings. Overall, our observations of behaviour indicate a slower but somewhat smoother transition to a motionless state in the biphasic hypercapnic hyperoxygenation treatment compared with the hypercapnic anoxic treatment.

During the baseline period, heart rate fell steadily and respiration rate fell slightly as the birds recovered from handling. It was not possible to continue the measurement of respiration rate once the birds had entered the gas tunnel owing to the number of immeasurable traces that disrupted the recording system, caused by wing flapping, leg paddling, tonic pectoral muscle contractions and jostling by other birds. Heart rate throughout the first $100 \mathrm{~s}$ of gas stunning was similar for both gases and its dynamic change over time followed a similar pattern to that observed for both individuals and groups of birds in the pilot scale system (Abeyesinghe et al., 2007). More detailed analysis of the ECG traces in the latter study showed evidence of bradycardia and arrhythmia with both gas treatments. The loss of traces was greater for $\mathrm{Ar}+\mathrm{CO}_{2}$ than $\mathrm{CO}_{2}+\mathrm{O}_{2}$, probably due to the loss of the sensor and signals and supporting the conclusion that experience of an anoxic hypercapnic gas mixture causes a more vigorous behavioural response in broiler chickens. Such intense and long lasting artefacts in the trace may indicate strong isometric muscle contractions which are likely to be painful and which occur during a period when consciousness cannot be excluded (McKeegan et al, 2006).

In terms of carcase quality there appears to be clear advantages to the processor and the consumer in using $\mathrm{CO}_{2}+\mathrm{O}_{2}$ than $\mathrm{Ar}+\mathrm{CO}_{2}$ to stun broiler chickens, particularly because of a much smaller number of fractured wings. Based upon a commercially relevant number of carcases that were examined for wing fracture $(\approx 19,000)$, the overall prevalence of wing fractures was 4 times worse in $\mathrm{Ar}+\mathrm{CO}_{2}$ than $\mathrm{CO}_{2}+\mathrm{O}_{2}$. Notably, a large proportion of these 
fractures led to skin perforation, which can be attributed to the more violent movements and convulsions of birds stunned with $\mathrm{Ar}+\mathrm{CO}_{2}$ compared with $\mathrm{CO}_{2}+\mathrm{O}_{2}$. If these fractures occurred when the birds were conscious, then welfare as well as carcass quality would be severely compromised.

CAS has been shown to produce meat of superior quality when compared with electrical stunning (Raj et al., 1997; Uijttenboogaart et al., 1997; Hoen and Lankhaar, 1999). Compared with $\mathrm{Ar}+\mathrm{CO}_{2}, \mathrm{CO}_{2}+\mathrm{O}_{2}$ stunning induced fewer haemorrhages in the fillets. Differences between the gases in the fall in fillet $\mathrm{pH}$ post mortem appear to be associated with the behaviour of the birds during stunning, confirming the results of the pilot plant study (Abeyesinghe et al., 2007). The more pronounced peri mortem struggles, such as wing flapping and leg paddling, in $\mathrm{Ar}+\mathrm{CO}_{2}$ accelerated glycolysis and lactate accumulation, as shown by the low pH 15 min after slaughter. These results contrast with our earlier study (Abeyesinghe et al., 2007), where the rate of fall of $\mathrm{pH}$ decline was similar in $\mathrm{CO}_{2}+\mathrm{O}_{2}$ and $\mathrm{Ar}+\mathrm{CO}_{2}$ stunned birds. This may be due to the very rapid decline in $\mathrm{pH}$ observed for $\mathrm{Ar}+\mathrm{CO}_{2}$ in this study, which was probably the result of vigorous wing flapping. Storage and cooking losses were similar to those recorded in our pilot study and were unaffected by stunning treatment (Abeyesinghe et al., 2007).

Raj et al. (1991) found that the majority of broilers stunned by argon attained rigor mortis within $20 \mathrm{~min}$, enabling carcases to be filleted $2 \mathrm{~h}$ post mortem without affecting meat texture. The low $\mathrm{pH}$ values measured after $15 \mathrm{~min}$ post mortem for $\mathrm{Ar}+\mathrm{CO}_{2}$ are in accordance with these results. However, our measurements of toughness (shear force, $\mathrm{t}_{0}$ ) indicate that for both stunning CAS methods, carcases took up to $7 \mathrm{~h}$ to attain full rigor mortis. In commercial in-line poultry processing, carcases are portioned and de-boned after 2 to $3 \mathrm{~h}$ post mortem, with a risk of tough meat when CAS is used. This problem can be overcome by electrical stimulation of the carcase to allow in-line de-boning, typically $3 \mathrm{~h}$ post mortem, without the risk of tough meat (Kranen, 2003). This solution is adopted commercially in many European abattoirs as one stage in processing broiler carcases for meat.

The lightness of the meat is indicated by its $\mathrm{L}^{*}$ value, which is inversely proportional to muscle pH (Qiao et. al., 2001). This was indeed true for the distal (exterior) surface of $\mathrm{CO}_{2}+\mathrm{O}_{2}$ fillets, which became lighter over time post slaughter as $\mathrm{pH}$ fell. However, this relationship did not appear to hold for $\mathrm{Ar}+\mathrm{CO}_{2}$ fillets, indicating that muscle colour is not only determined by muscle $\mathrm{pH}$.

The results of this study have direct application to the practical conditions of the commercial processing plant. Unlike laboratory experiments, the birds experienced the full range of environmental and social stressors during stunning. These relate to the presence of other birds in the gas tunnel, which may cause physical interference or whose behaviour, vocalisations and other reactions may be perceived perhaps adversely; process control of the 
atmospheric and thermal environment, which is so influential in ensuring rapid exposure to the correct concentration of gases at an appropriate temperature and humidity; and the experience of the birds during transport from the farm to the lairage. Indeed, the methods employed here could be used to determine the causes of poor welfare and meat quality from the farm to the abattoir, identifying the risk factors responsible and suggesting improvements. Risk factors that might be addressed include: the merits of gas stunning within or outwith transport crates; and the benefits and drawbacks of electrical stunning versus CAS. The advantages of biphasic CAS over electrical stunning of poultry were also recognised at a symposium on this topic (Barton Gade et al., 2000). It is only by integration of studies in the laboratory and commercial plants using techniques from a range of scientific and engineering disciplines that progress can be made to the benefit of the bird, processor and consumer alike (Wathes, 2005).

This and the accompanying paper (Abeyesinghe et al., 2007) form part of a coordinated series of experiments (Lowe et al., 2007; McKeegan, 2004; McKeegan et al., 2006) that have examined the effects of CAS on broiler chickens. We have studied the three distinct approaches that can be used in controlled atmosphere stunning of broiler chickens, viz anoxia, hypercapnic anoxia and a combination of hypercapnic hyperoxygenation anaesthesia and hypercapnic euthanasia. The strengths of this coordinated study lie in firstly, the comprehensive range of techniques employed to measure behavioural and physiological responses that are indicative of welfare, and physico-chemical properties of the carcase and meat that describe the organoleptic and aesthetic appeal of chicken meat; secondly, the location and scale of study from the laboratory to the processing plant; and thirdly, the different physiological approaches used to stun the birds. Interpretation of the behavioural and physiological data is complex and we do not believe that it is wise to speculate on which of our findings are indicative of pain without direct measurements. Such measurements are either extremely difficult or impossible to undertake in a commercial abattoir at present. Fractures are clearly likely to be painful if experienced by a conscious bird, and although we cannot tell from this experiment when they occurred, they were 4 times more prevalent in $\mathrm{Ar}+\mathrm{CO}_{2}$ than $\mathrm{CO}_{2}+\mathrm{O}_{2}$. Measurements relating to loss of consciousness were not carried out in this experiment but in all other respects the results support the findings of our laboratory studies (McKeegan et al. 2006) which suggested that early onset wing flapping during anoxia occurs during periods in which a form of consciousness cannot be excluded. In terms of the two CAS approaches investigated here, we conclude that a biphasic approach based upon consecutive phases of anaesthesia and euthanasia is potentially more humane than an anoxic hypercapnic approach. It is also superior in terms of carcase and meat quality.

\section{ACKNOWLEDGEMENTS}


The behavioural and physiological aspects of this work were funded by the Department for Environment, Food and Rural Affairs, UK, while those relating to meat and carcase quality and the use of the processing plant were funded by Stork PMT and Yara International ASA.

\section{REFERENCES}

ABEYESINGHE, S.M., MCKEEGAN, D.E.F., MCLEMAN, M.A., LOWE, J.C., DEMMERS, T.G.M., WHITE, R.P., KRANEN, R.W., BEMMEL, H. VAN, LANKHAAR, J.A.C. \& WATHES, C.M. (2007) Controlled atmosphere stunning of broiler chickens: I. Effects on behaviour, physiology and meat quality in a pilot scale system at a processing plant. British Poultry Science.In press.

ANIL, M.H., PRESTON, J., MCKINSTRY, J.L., RODWAY, R.G. \& BROWN, S.N. (1996) An assessment of stress caused in sheep by watching slaughter of other sheep. Animal Welfare, 5: 435-441.

BARTON GADE, P., HOLLEBEN, K. VAN \& WENZLAWOWICZ, M. VON (2001) Animal welfare and controlled atmosphere stunning of poultry using mixtures of carbon dioxide and oxygen. World's Poultry Science Journal, 57: 189-200.

COENEN, A., SMIT, A., ZHONGHUA, L. \& LUIJTELAAR, G. VAN (2000) Gas mixtures for anaesthesia and euthanasia in broiler chickens. World's Poultry Science Journal, 56: 225234.

GERRITZEN, M.A., LAMBOOIJ, E., HILLEBRAND, S.J.W., LANKHAAR, J. \& PIETERSE, C. (2000) Behavioural responses of broilers to different gaseous atmospheres. Poultry Science, 79: 928-933.

HOEN, T. \& LANKHAAR, J. (1999) Controlled atmosphere stunning of poultry. Poultry Science, 78: 287-289.

KRANEN, R. W. (2003) Rapid rigor: the way to accelerate in-line poultry processing. Proceedings of the XVI ${ }^{\text {th }}$ European Symposium on the quality of poultry meat. Vol. II Quality of poultry meat. Saint-Brieuc, France, pp 666-671.

LAMBOOIJ, E., GERRITZEN, M.A., ENGEL, B., HILLEBRAND, S.J.W., LANKHAAR, J. \& PIETERSE, C. (1999) Behavioural responses during exposure of broiler chickens to different gas mixtures. Applied Animal Behaviour Science, 62: 255-265.

LOWE, J.C., ABEYESINGHE, S.M., DEMMERS, T.G.M., WATHES, C.M. \& MCKEEGAN, D.E.F. (2007) A novel telemetric logging system for recording physiological signals in unrestrained animals. Computers and Electronics in Agriculture. In press MCKEEGAN, D.E.F. (2004) Mechano-chemical nociceptors in the avian trigeminal mucosa. Brain Research Reviews, 46: 146-154. 
MCKEEGAN, D.E.F., MCINTYRE, J., DEMMERS, T.G.M., WATHES, C.M. \& JONES, R.B. (2006) Behavioural responses of broiler chickens during acute exposure to gaseous stimulation. Applied Animal behaviour Science, 99: 271-286.

MCKEEGAN, D.E.F., MCINTYRE, J., DEMMERS, T.G.M., LOWE, J.C., WATHES, C.M. BROEK, P.L.C. VAN DEN, COENEN, A.M.L. \& GENTLE, M.J. (2007) Physiological and behavioural responses of broilers to controlled atmosphere stunning - implications for welfare. Animal Welfare. In press

QIAO, M., FLETCHER, D. L., SMITH, D. P., \& NORTHCUTT, J. K. (2001) The effect of broiler breast meat colour on $\mathrm{pH}$, moisture, water-holding capacity, and emulsification capacity. Poultry Science, 80: 676-680.

RAJ, A.B.M. \& GREGORY, N.G. (1990) Investigation into the batch stunning/killing of chickens using carbon dioxide or argon-induced hypoxia. Research in Veterinary Science, 49: 363-366.

RAJ, A.B. M., GREY, T.C. \& GREGORY, N.G. (1991) Effect of early filleting on the texture of breast muscle of broilers stunned with argon-induced anoxia. British Poultry Science, 32: 319-325.

RAJ, A.B.M., WOTTON, S.B., MCKINSTRY, J.L., HILLEBRAND, S.J.W. \& PIETERSE, C. (1998) Changes in the somatosensory evoked potentials and spontaneous electroencephalogram of broiler chickens during exposure to gas mixtures. British Poultry Science, 39: 686-695.

RAJ, A.B.M., L.J. WILKINS, R.I. RICHARDSON, S.P. JOHNSON, \& S.B. WOTTON (1997). Carcase and meat quality in broilers either killed with a gas mixture or stunned with an electrical current under commercial processing conditions. British Poultry Science, 38 : 169-174.

RAJ, A.B.M. \& TSERVENI-GOUSI, A. (2000) Stunning methods for poultry. World's Poultry Science Journal, 56: 291-304.

UIJTTENBOOGAART, T.G. (1997). Effects of gas and electrical stunning methods on meat quality. Proceedings Symposium: Alternative stunning methods for poultry, Utrecht, The Netherlands, E. Lambooij ed. ID-DLO nr. 97.037, pp 25-33.

WATHES, C.M. (2005) Report of a workshop on controlled atmosphere stunning of poultry: an integrated approach. Animal Welfare, 14: 85-86.

WEBSTER, A,B. \& FLETCHER, D.L. (2000) Reactions of laying hens and broilers to different gas used for stunning poultry. Poultry Science, 80: 1371-1377.

WOOLLEY, S.C. \& GENTLE, M.J. (1988) Physiological and behavioural responses of the domestic hen to hypoxia. Research in Veterinary Science, 45: 377-382. 
Table 1. Measurements of carcase and meat quality in broiler chickens stunned by gas.

\begin{tabular}{lll}
\hline Measurement & $\begin{array}{l}\text { Replicates per } \\
\text { treatment per } \\
\text { flock }\end{array}$ & $\begin{array}{l}\text { Method, see Abeyesinghe } \text { et } \\
\text { al. (2007) }\end{array}$ \\
\hline
\end{tabular}

Stunning, killing and

bleeding

Wing fracture $\quad \approx 750$ carcasses $\quad$ Palpation after stunning

Blood loss

10

Gravimetric

Evisceration and chilling

$\begin{array}{lcl}\text { Liver colour } & 50 & \begin{array}{l}\text { Classification on a three point } \\ \text { scale }\end{array} \\ \text { Plucking efficiency } & 24 & \begin{array}{l}\text { Count } \\ \text { Classification on a two point } \\ \text { scale, summed separately by } \\ \text { scratches and bruises on back, } \\ \text { breast, legs, wing tips and tail }\end{array}\end{array}$

De-boning ${ }^{1}$

Fillet $\mathrm{pH}^{2}$

$6^{3}$

$\mathrm{pH}$ sensor

Fillet meat colour $\quad 6^{3}$

Spectrophotometric using

CIELab classification

Shear force $\left(t_{0}, N\right) \quad 6^{3}$

Mechanical using a Warner

Bratzler device

Haemorrhages 24

Classification on a three point scale

Fractured bones $\quad 24$

Palpation

$\underline{\text { Storage and cooking }}{ }^{4}$

Storage loss

$6 \quad$ Gravimetric

Cooking loss 6

Gravimetric

Shear force $\left(t_{24}, N\right) \quad 6$

Mechanical using a Warner

Bratzler device

${ }^{1}$ Carcases were de-boned at $15 \mathrm{~min}, 1.5,3,5,7$ and $24 \mathrm{~h}$ post mortem .

${ }^{2} \mathrm{n}=20$ carcases at $15 \mathrm{~min}$ post mortem.

${ }^{3}$ Number of carcases per treatment per flock per de-boning time.

${ }^{4}$ Fillet halves were stored for $24 \mathrm{~h}$ until measurements were made. 
Table 2. Effects of stunning gas on blood loss, liver colour, carcase quality and muscle haemorrhages in broiler chickens stunned by gas during various stages of processing.

\begin{tabular}{|c|c|c|c|c|}
\hline & \multirow{2}{*}{$\mathrm{Ar}+\mathrm{CO}_{2}$} & \multirow{2}{*}{$\mathrm{CO}_{2}+\mathrm{O}_{2}$} & \multicolumn{2}{|c|}{ Gas } \\
\hline & & & $P$ & s.e.d. \\
\hline \multicolumn{5}{|l|}{ Blood loss, $g$ per bird $^{1}$} \\
\hline at $90 \mathrm{~s}$ after stunning & 59.1 & 57.1 & ns & 2.46 \\
\hline at $150 \mathrm{~s}$ after stunning & 65.7 & 65.9 & ns & 2.09 \\
\hline Liver colour, mean score per carcase $^{2}$ & 2.23 & 2.17 & ns & na \\
\hline $\begin{array}{l}\text { Plucking efficiency, proportion of carcases with } \\
>=2 \text { feathers remaining per bird }\end{array}$ & 0.85 & 0.81 & ns & 0.044 \\
\hline \multicolumn{5}{|l|}{ Skin damage, mean score per carcase } \\
\hline $\begin{array}{l}\text { carcase scratches, } \log _{\mathrm{e}} \\
\text { carcase bruises }\end{array}$ & $\begin{array}{l}1.03 \\
8.18\end{array}$ & $\begin{array}{l}1.13 \\
8.11\end{array}$ & $\begin{array}{l}\mathrm{ns} \\
\mathrm{ns}\end{array}$ & $\begin{array}{l}0.114 \\
0.713\end{array}$ \\
\hline \multicolumn{5}{|l|}{ Wing fractures, mean proportion of wings ${ }^{3}$} \\
\hline breakage & 0.047 & 0.012 ) & & \\
\hline breakage with skin perforation & 0.021 & $0.004)$ & $<0.001$ & 0.0049 \\
\hline intact & 0.932 & $0.984)$ & & \\
\hline \multicolumn{5}{|l|}{ Other fractures, mean proportion of carcases } \\
\hline $\begin{array}{l}\text { W1snbone with haemorrhaging } \\
\text { coracoid }\end{array}$ & $\begin{array}{l}0.215 \\
0.008\end{array}$ & .183 & $\begin{array}{l}\mathrm{ns} \\
\mathrm{ns}\end{array}$ & $\begin{array}{c}0.054 \\
0.0083\end{array}$ \\
\hline shoulder blade & 0.008 & 0 & ns & 0.0083 \\
\hline \multicolumn{5}{|l|}{ Haemorrhages, mean score } \\
\hline fillet (distal surface) & 0.32 & 0.19 & 0.05 & 0.056 \\
\hline tenderloin (distal surface) & 0.05 & 0.04 & ns & - \\
\hline thigh & 0.33 & 0.30 & ns & 0.044 \\
\hline shoulder joint & 0.25 & 0.28 & ns & 0.034 \\
\hline
\end{tabular}

${ }^{1}$ Using liveweight as a covariate.

${ }^{2}$ Comparison of frequency distributions after logit transformation.

${ }^{3}$ Analysis of deviance, s.e.d.'s are approximate where given.

ns - not significant; na - not applicable; number of replicates given in Table 1. 
Table 3. Dynamic changes in fillet pH, shear force, and storage and cooking losses in broiler chickens stunned by gas.

\begin{tabular}{|c|c|c|c|c|c|c|c|c|c|c|c|c|}
\hline & \multicolumn{6}{|c|}{ Time post slaughter, $\mathrm{h}$} & \multicolumn{2}{|c|}{ Gas } & \multicolumn{2}{|c|}{ time } & \multicolumn{2}{|c|}{ time.gas interaction } \\
\hline & 0.25 & 1.5 & 3 & 5 & 7 & 24 & s.e.d. & $P$ & s.e.d. & $\mathrm{p}$ & s.e.d. & $\mathrm{p}$ \\
\hline \multicolumn{13}{|l|}{ Fillet $\mathrm{pH}$} \\
\hline $\mathrm{Ar}+\mathrm{CO}_{2}$ & 6.00 & 6.04 & 5.99 & 5.97 & 5.98 & 5.97 & 0.021 & $<0.001$ & 0.039 & $<0.001$ & 0.055 & $<0.001$ \\
\hline $\mathrm{CO}_{2}+\mathrm{O}_{2}$ & 6.32 & 6.48 & 6.38 & 6.04 & 5.97 & 5.95 & & & & & & \\
\hline \multicolumn{13}{|c|}{ Shear force, $\left(\mathrm{t}_{0}, \mathrm{~N}\right), \ln$} \\
\hline $\begin{array}{l}\mathrm{Ar}+\mathrm{CO}_{2} \\
\mathrm{CO}_{2}+\mathrm{O}_{2}\end{array}$ & - & $\begin{array}{l}4.94 \\
4.86\end{array}$ & $\begin{array}{l}4.73 \\
4.93\end{array}$ & $\begin{array}{l}4.28 \\
4.53\end{array}$ & $\begin{array}{l}3.67 \\
3.74\end{array}$ & $\begin{array}{l}2.95 \\
3.07\end{array}$ & 0.043 & 0.05 & 0.076 & $<0.001$ & 0.105 & $\mathrm{~ns}$ \\
\hline \multicolumn{13}{|c|}{ Shear force, $\left(\mathrm{t}_{24}, \mathrm{~N}\right), \ln$} \\
\hline $\begin{array}{l}\mathrm{Ar}+\mathrm{CO}_{2} \\
\mathrm{CO}_{2}+\mathrm{O}_{2}\end{array}$ & - & $\begin{array}{l}3.95 \\
4.14\end{array}$ & $\begin{array}{l}3.60 \\
3.91\end{array}$ & $\begin{array}{l}3.32 \\
3.52\end{array}$ & $\begin{array}{l}3.05 \\
3.18\end{array}$ & $\begin{array}{l}2.87 \\
2.85\end{array}$ & 0.028 & 0.002 & 0.073 & $<0.001$ & 0.097 & ns \\
\hline \multicolumn{13}{|c|}{ Storage loss, $\%$} \\
\hline $\mathrm{Ar}+\mathrm{CO}_{2}$ & - & 0.55 & 0.53 & 0.44 & 0.40 & 0.56 & 0.019 & ns & 0.063 & ns & 0.081 & ns \\
\hline $\begin{array}{c}\mathrm{CO}_{2}+\mathrm{O}_{2} \\
\text { Cooking lo }\end{array}$ & - & 0.51 & 0.50 & 0.49 & 0.35 & 0.50 & Cooking loss, \% & & & & & \\
\hline $\mathrm{Ar}+\mathrm{CO}_{2}$ & - & 27.4 & 25.6 & 25.0 & 24.7 & 24.7 & 0.455 & ns & 1.486 & ns & 1.934 & ns \\
\hline $\mathrm{CO}_{2}+\mathrm{O}_{2}$ & - & 26.1 & 26.0 & 24.8 & 24.9 & 23.7 & & & & & & \\
\hline
\end{tabular}

Number of replicates given in Table 1. 
Table 4. Dynamic changes in the colour of fillets of broiler chickens stunned by gas.

\begin{tabular}{|c|c|c|c|c|c|c|c|c|c|c|c|}
\hline & \multicolumn{5}{|c|}{ Time post slaughter, $\mathrm{h}$} & \multicolumn{2}{|c|}{ Gas } & \multicolumn{2}{|c|}{ Time } & \multicolumn{2}{|c|}{ time.gas interaction } \\
\hline & 1.5 & 3 & 5 & 7 & 24 & s.e.d. & $P$ & s.e.d. & $P$ & s.e.d. & $\mathrm{p}$ \\
\hline $\mathrm{L}^{*}$ proximal & & & $5=$ & & & & & & & & \\
\hline $\mathrm{Ar}+\mathrm{CO}_{2}$ & 57.0 & 57.7 & 57.4 & 58.5 & 57.4 & & & & & & \\
\hline $\mathrm{CO}_{2}+\mathrm{O}_{2}$ & 57.7 & 58.6 & 59.4 & 59.3 & 59.8 & 0.424 & ns & 0.678 & ns & 0.952 & $\mathrm{~ns}$ \\
\hline \multicolumn{12}{|l|}{$\mathrm{L}^{*}$ distal } \\
\hline $\mathrm{Ar}+\mathrm{CO}_{2}$ & 58.5 & 59.8 & 60.9 & 61.1 & 60.7 & & & & & & \\
\hline $\mathrm{CO}_{2}+\mathrm{O}_{2}$ & 59.3 & 60.8 & 61.8 & 62.1 & 63.1 & 0.222 & 0.003 & 0.559 & $<0.001$ & 0.740 & ns \\
\hline $\mathrm{a}^{*}$ proximal & 4.82 & 4.52 & 4.30 & 4.89 & 4.80 & & & & & & \\
\hline $\begin{array}{l}\mathrm{Ar}+\mathrm{CO}_{2} \\
\mathrm{CO}_{2}+\mathrm{O}_{2}\end{array}$ & 4.79 & 4.40 & 4.23 & 4.51 & 4.16 & 0.212 & ns & 0.209 & ns & 0.339 & ns \\
\hline$a^{*}$ distal & 4.08 & 3.45 & 3.30 & 4.17 & 3.91 & & & & & & \\
\hline $\begin{array}{l}\mathrm{Ar}+\mathrm{CO}_{2} \\
\mathrm{CO}_{2}+\mathrm{O}_{2}\end{array}$ & 3.88 & 3.44 & 3.31 & 3.38 & 3.32 & 0.172 & ns & 0.177 & 0.004 & 0.282 & ns \\
\hline $\mathrm{b}^{*}$ proximal & 12.8 & 12.5 & 12.0 & 12.6 & 11.1 & & & & & & \\
\hline $\begin{array}{l}\mathrm{Ar}+\mathrm{CO}_{2} \\
\mathrm{CO}_{2}+\mathrm{O}_{2}\end{array}$ & 13.7 & 13.3 & 12.6 & 12.6 & 12.0 & 0.374 & ns & 0.423 & 0.003 & 0.649 & ns \\
\hline $\mathrm{b}^{*}$ distal & 9.9 & 10.2 & 10.2 & 10.5 & 10.0 & & & & & & \\
\hline $\begin{array}{l}\mathrm{Ar}+\mathrm{CO}_{2} \\
\mathrm{CO}_{2}+\mathrm{O}_{2} \\
\end{array}$ & 10.9 & 11.2 & 10.7 & 11.1 & 10.8 & 0.119 & 0.001 & 0.308 & ns & 0.407 & ns \\
\hline
\end{tabular}

Number of replicates given in Table 1 . 